\title{
Intake and digestibility of nutrients during the grazing period in sheep on deferred marandu pastures with four initial heights
}

\section{Consumo e digestibilidade dos nutrientes durante o período seco em ovinos em pasto diferido com quatro alturas iniciais}

\begin{abstract}
Jhonatan Gonçalves Silva ${ }^{1}$; Letícia Marques da Fonseca²; Laura Andrade Reis ${ }^{3}$; Dallety Haloma Alves Miler de Oliveira ${ }^{3}$; Natascha Almeida Marques da Silva4; Manoel Eduardo Rozalino Santos ${ }^{4}$; Simone Pedro da Silva ${ }^{4 *}$
\end{abstract}

\section{Highlights}

Low pasture height at the beginning of deferment period improves the forage quality.

The nutritional value of deferred pasture decreases with grazing period in the winter.

Deferred pasture intake by sheep is reduced during the winter grazing period.

Deferred pasture intake by sheep ranged from 1.10 to $1.63 \%$ body weight.

\section{Abstract}

The objective of this study was to verify the effect of reducing in pasture height at the beginning of the deferment period (PHBD) of Brachiaria brizantha cv. Marandu on nutrient intake and digestibility in sheep during winter. The combinations between average sward heights $(15,25,35$ and $45 \mathrm{~cm})$ at the beginning of the deferment period and the times of sward use during the winter were evaluated; intake and digestibility evaluations were carried out at the beginning, middle and end of the grazing period, which lasted 90 days. The experimental design used was completely randomized, with three replications. The parameters evaluated were: intake and digestibility of dry matter (DM), crude protein (CP) and neutral detergent fiber (NDF) and potentially digestible dry matter (pDDM). The pDDM contents were similar in pastures kept with 15 and $25 \mathrm{~cm}$, but higher than those observed in pastures with 35 and $45 \mathrm{~cm}$ at the beginning of the deferment period. The NDF contents were lower and the CP and NDF digestibility were higher in 15 and $25 \mathrm{~cm}$ deferred pastures than in $35 \mathrm{~cm}$ at the beginning of deferment period, except for pastures lowered to $45 \mathrm{~cm}$. The

1 Master's Degree Student of Post Graduate Program in Veterinary Sciences, Faculdade de Medicina Veterinária, FAMEV, Universidade Federal de Uberlândia, UFU, Uberlândia, MG, Brazil. E-mail: jhonatan.zootec@hotmail.com

2 Veterinarian, FAMEV, UFU, Uberlândia, MG, Brazil. E-mail: leticiavetufu80@gmail.com

3 Students in Animal Science, FAMEV, UFU, Uberlândia, MG, Brazil. E-mail: lauraandradereis@gmail.com; datymiler16@ gmail.com

${ }^{4}$ College Profs., of Animal Science and Veterinary, FAMEV, UFU, Uberlândia, MG, Brazil. E-mail: manoel.rozalino@ufu. br; natascha@ufu.br; simone.psilva@hotmail.com

* Author for correspondence

Received: June 21, 2021 - Approved: Oct. 01, 2021 
improvement in nutritional value of the forage apparently ingested by sheep, promoted by ISP reduction, did not result in a variation in pasture consumption by the animals. DMI, expressed as percentage of body weight (\%BW), ranged from 1.10 to 1.63 . At the beginning of the grazing period, higher values of pDDM, CP and DM digestibility (DMD) were verified in simulated grazing samples. The same response pattern observed for nutritional value traits also occurred for DMI (g.day-1 and \%BW) and CP intake. These were higher at the beginning, than at the middle and end of the grazing period. The use of lower sward heights at the beginning of the deferment period allowed the production of pasture with better nutritional quality, but these changes in the nutritional value of the pasture were insufficient to result in higher nutrient intake and digestibility. Furthermore, there was a reduction in nutritional value of the forage apparently consumed by sheep, in the intake and digestibility of deferred pastures throughout the grazing period, in winter. The lower pastures at the beginning of the deferment period $(15 \mathrm{~cm})$ improves the nutritional value of forage and nutrient digestibility at the beginning of the winter grazing period. The nutritional value and intake of deferred forage by sheep are compromised by the grazing period.

Key words: Pasture deferment. iNDF. LIPE. CP. Potentially digestible dry matter (pDDM).

\section{Resumo}

O objetivo do presente estudo foi verificar o efeito das reduções na altura do pasto no início do período de diferimento (APID) de Brachiaria brizantha cv. Marandu sobre o consumo e digestibilidade dos nutrientes em ovinos durante o inverno. Foram avaliadas as combinações entre as alturas médias dos pastos $(15,25$, 35 e $45 \mathrm{~cm}$ ) no início do período de diferimento e os tempos de utilização dos pastos durante o inverno. As avaliações de consumo e digestibilidade foram realizadas no início, meio e final do período de pastejo, que foi de 90 dias. O delineamento experimental utilizado foi inteiramente casualizado, com três repetições. Os parâmetros avaliados foram: consumo e digestibilidade da matéria seca (MS), proteína bruta (PB) e fibra em detergente neutro (FDN) e matéria seca potencialmente digestível (MSpd). Os teores de MSpd foram semelhantes nos pastos mantidos com 15 e $25 \mathrm{~cm}$, mas superiores aos observados nos pastos com 35 e $45 \mathrm{~cm}$ no início do período de diferimento. Os teores de FDN foram menores e as digestibilidades de PB e FDN foram maiores nas pastagens diferidas com 15 e $25 \mathrm{~cm}$, do que com $35 \mathrm{~cm}$ no início do período de diferimento, exceto para os pastos rebaixados para $45 \mathrm{~cm}$. A melhora no valor nutricional da forragem aparentemente ingerida pelos ovinos, promovida pela redução da APID, não resultou em variação no consumo de forragem pelos animais. O CMS, expresso em porcentagem do peso corporal (\% PC), variou de 1,10 a 1,63. No início do período de pastejo, maiores valores de MSpd, PB e digestibilidade da MS (DMS) foram verificados nas amostras de pastejo simulado. A utilização de alturas menores do pasto no início do período de diferimento permitiu a produção de pastagens com melhor qualidade nutricional, mas essas alterações no valor nutricional da forragem foram insuficientes para resultar em maior consumo e digestibilidade dos nutrientes. Além disso, houve redução no valor nutricional da forragem aparentemente consumida pelos ovinos, no consumo e na digestibilidade dos pastos diferidos ao longo do período de pastejo, durante o inverno. Os pastos mais baixos no início do período de diferimento $(15 \mathrm{~cm})$ tiveram melhor valor nutricional e digestibilidade dos nutrientes. O valor nutricional e consumo de forragem diferida por ovinos são comprometidos ao longo do período de pastejo.

Palavras-chave: Pastagem diferida. FDNi. LIPE®. Matéria seca potencialmente digestível (MSpd). 


\section{Introduction}

Pasture deferment is a management strategy used to guarantee stock of mass forage for use during the winter in pastoral systems (C. S. Silva, Montagner, Euclides, Queiroz, \& Andrade, 2016). However, the limitation of this technique is the fact of producing a pasture with worse morphology and, with effect, damage to the nutritional value (Sousa et al., 2012; Vilela et al., 2012). Nutritional limitations of the deferred pasture are related to the advanced stage of plant development and climate limiting the growth, however predisposing to pasture senescence the during the winter. As consequence, forage consumed by the animals usually has low nutritional value, which reduces grass intake by animals on pasture (P. H. F. Silva et al., 2019).

In this scenario, so that the deferred pastures do not present elevated forage mass with limited nutritional value, it has been recommended to reduce the sward height, to adopt intense grazing of shortly duration, in initial deferment period the pasture, with less demanding animal categories (Afonso et al., 2018). With that, the removal of old forage with low quality, and the increased incidence of light on the base of plants stimulate the appearance of new tillers (Santana et al., 2014; Carvalho, Pereira, Sbrissia, Rocha, \& Santos, 2021). These younger tillers, in turn, have higher percentage of live leaves and less percentage of dead leaves (Santos et al., 2018), they are less prone to the florescence, besides having better nutritional value (Santos et al., 2008). As a consequence, the improvement in morphology and the nutritional value of the deferred pasture has great potential to optimize the animal intake and performance in pasture.
It is worth pointing out few scientific studies where nutrient intake and digestibility have been carried out with sheep on deferred pasture of Brachiaria brizantha cv. Marandu. This grass occupies great part of the area cultivated in pasture production systems, being heavily used in the Cerrado region of Brazil (Paula et al., 2012), because of its adaptation to tropical climate and tolerance to acid soils with medium fertility. The few existing studies used protein and energy supplementation to increase sheep production on pasture (Almeida et al., 2009). However, it is important to know the intake level of animals on deferred pastures, without supplementation. Additionally, it is also relevant to check the effects of pasture management strategies, such as the variation in pasture height at the beginning of the deferment period, on the quality of this feed, subsequently, to propose more appropriate actions of supplementation, aiming to reduce production costs.

It is important to recognize that during the grazing period in the winter, morphological characteristics and nutritional value of deferred pastures are negatively changed (C.S. Silva et al., 2016; P. H. F. Silva et al., 2019), thus, it is important to know how the concentration of nutrients in the deferred pasture changes over the grazing period and the way in which this modifies the pasture intake by the animal and the nutrient digestibility. This knowledge is essential, for example, to propose adjustments in the amount and quality of concentrate supplements to be provided to animals on deferred pasture during the winter (Alves et al., 2014; P. H. F. Silva et al., 2019).

Given the above, we tested the following hypotheses: (i) low pasture height at the beginning of the deferment period 
allows the production of deferred pasture with better nutritional quality, higher nutrient intake and digestibility, with less variation in these characteristics along the grazing period; (ii), during the winter grazing period, the nutritional value of forage apparently consumed by sheep, as well as the deferred pasture intake and digestibility, decrease. This study was conducted with the objective of verifying the effect of different sward heights of Brachiaria brizantha cv. Marandu at the beginning of the deferment period on the forage nutritional value, nutrient intake and digestibility in sheep during the winter grazing period.

\section{Material and Methods}

The experiment was conducted at the Experimental Farm Capim Branco of Universidade Federal de Uberlândia (UFU), in Uberlândia, state of Minas Gerais. The climate in the region, according to the Köppen classification, is Aw, tropical savanna (Alvares, Stape, Sentelhas, Gonçalves, \& Sparovek, 2013), with mild and dry winter, with welldefined dry and rainy seasons, average annual temperature of $22.3^{\circ} \mathrm{C}$ and average annual rainfall of $1,584 \mathrm{~mm}$. During the experiment, information about weather conditions were monitored (Table 1).

\section{Table 1}

Average air temperature, average solar radiation and rainfall during the experimental period

\begin{tabular}{|c|c|c|c|c|c|}
\hline \multirow{2}{*}{ Period } & \multicolumn{3}{|c|}{ Average air temperature $\left({ }^{\circ} \mathrm{C}\right)$} & \multirow{2}{*}{$\begin{array}{l}\text { Solar Radiation } \\
\text { (Mj/day) }\end{array}$} & \multirow{2}{*}{$\begin{array}{c}\text { Rainfall } \\
(\mathrm{mm})\end{array}$} \\
\hline & Mean & Minimum & Maximum & & \\
\hline Beginning of the grazing period & 20.33 & 12.70 & 29.10 & 414.86 & 10.4 \\
\hline Middle of the grazing period & 19.11 & 8.20 & 31.30 & 456.78 & 0 \\
\hline End of the grazing period & 20.45 & 7.40 & 30.90 & 537.59 & 0 \\
\hline
\end{tabular}

The experiment took place in a pasture of Brachiaria brizantha cv. Marandu (marandu grass), subdivided into 12 paddocks (experimental units) with $800 \mathrm{~m}^{2}$. Four pasture heights were evaluated under continuous stocking $(15,25,35$ and $45 \mathrm{~cm})$ at the beginning of the deferment period of 79 days, which was the same for all paddocks. These evaluations took place at the beginning (7th day), middle (45th day) and end (90th day) of grazing period, throughout the winter, in the months of June, July, August and September. The experimental design was completely randomized, with three replications.
Before the deferral period, all paddocks were managed under continuous stocking, with sheep and variable stocking rate to maintain the desired average height of pastures $(15,25,35$ and $45 \mathrm{~cm})$. In April, the deferment period of 79 days began, in which paddocks were managed without animals. After the deferment period, in late June, the grazing period for 90 days of all pastures began. In this grazing period, during the winter, 48 crossbred Santa Inês / Dorper sheep, with four months of age and average initial weight of $26 \mathrm{~kg}$ were used. Animals were allocated to paddocks at random, to keep four sheep per 
paddock, which corresponded to 2.8 animal unit (AU)/ha. Each animal unit corresponded to $450 \mathrm{~kg}$ body weight.

At the onset of the experiment, a soil sample was taken from the $0-20 \mathrm{~cm}$ layer, which presented the following results: $\mathrm{pH}$ $\left(\mathrm{H}_{2} \mathrm{O}\right): 6.1 ; \mathrm{P}: 4.5 \mathrm{mg}^{-3} \mathrm{dm}^{-3}$ (Mehlich-1); $\mathrm{K}^{+}$: 138.8 mg.dm ${ }^{-3} ; \mathrm{Ca}^{2+}: 5.5$ cmolc. $\mathrm{dm}^{-3} ; \mathrm{Mg}^{2+}: 1.9$ cmol.dm ${ }^{-3} ; \mathrm{Al}^{3+}: 0.0$ cmolc. $\mathrm{dm}^{-3}\left(1 \mathrm{~mol}^{-1} \mathrm{~L}^{-1} \mathrm{KCl}\right)$; Effective CTC: 7.3; CTC at pH 7.0: 10.2; and base saturation: $72.0 \%$. Based on these results and in accordance with the recommendations of R. B. Cantarutti, Alvares and Ribeiro (1999) for a medium technological level system, 50 kg.ha-1 $\mathrm{P}_{2} \mathrm{O}_{5}$ and $\mathrm{N}$ were applied in January, in addition to $70 \mathrm{~kg} \mathrm{ha}^{-1} \mathrm{~N}$, in March. Fertilizers used were single superphosphate and urea.

Animals remained on pasture for 90 days in all paddocks, during the winter. On three occasions during the grazing period (beginning, middle and end), forage intake was evaluated via hand plucking (E. H. B. K, Moraes, Paulino, Zervoudakis, Valadares, \& Moraes, 2005). The hang plucking method consists in observing the grazing habit of animals, and collected portions of plants similar to those taken by the animals. This procedure was carried out by a trained technician.

To estimate fecal output, purified and enriched lignin (LIPE) ${ }^{\circledR}$ was used, through the relationship between the dose administered and the fecal concentration of the external indicator. In this sense (LIPE) ${ }^{\circledR}$ was administered via esophageal probe, with a daily dosage of 0.5 g.animal.day ${ }^{-1}$ in capsules provided in the morning, once daily, during 6 days, being 2 days for adaptation and 4 days for fecal collection. Feces were collected directly from the animal rectum (Protocol CEUA Nº 058/18).
At the end of the collection period, a composite sample of the feces of each animal was made. Samples were dried, ground to a size of $1 \mathrm{~mm}$, for further analysis of the concentration of LIPE $^{\circledR}$. This determination was carried out by infrared spectroscopy, using the model appliance Watson Galaxy, series FT-IR 3000. Fecal output was calculated as described by Saliba et al. (2015). Feces were collected from the third day, after the supply of LIPE, for 4 days and at the same time as the supply of the capsules. The indigestible neutral detergent fiber (iNDF) was used as an internal indicator to estimate pasture intake.

DM intake was estimated as follows: $\mathrm{DMI}=$

$$
\left(\mathrm{FE}^{*} \mathrm{iNDF}_{\text {feces }}\right) / \mathrm{iNDF}_{\text {forage }}
$$

where: $\mathrm{DMI}=$ dry matter intake (g.day $\left.{ }^{-1}\right) ; \mathrm{FE}=$ fecal excretion (g.day ${ }^{-1}$ ); iNDF concentration in feces $\left({\left.\mathrm{g} . \mathrm{g}^{-1}\right)}\right.$ and iNDF concentration in forage $\left(g . g^{-1}\right)$.

The concentration of iNDF in hand plucked and feces samples were determined by incubation in non-woven fabric bags (NWF, $\left.100 \mathrm{~g} . \mathrm{m}^{-2}\right)$, in rumen fistulated Zebu cow for 240h (Valente et al., 2011).

Samples of hand plucked and feces were ground in a knife mill $(1 \mathrm{~mm})$ and placed in plastic pots. These samples were analyzed for dry matter (DM, method 934.01), organic matter (OM, method 942.05), crude protein (CP, method 954.01), and ether extract (EE, method 920.39) according to Association of Official Analytical Chemists [AOAC] (1990), and neutral detergent fiber (NDF), according to Mertens (2002). Determination of NDF was performed using $4.5 \times 5 \mathrm{~cm}$ NWF bags, containing an average of $14 \mathrm{mg} \mathrm{DM.cm}{ }^{-2}$ and $100 \mathrm{~mL}$ neutral detergent. 
To determine the potentially digestible DM (DMpd) of the hand plucked samples, the equation proposed by Paulino, Detmann and Valadares (2008) was used:

$$
\mathrm{DMpd}=0,98(100-\mathrm{NDF})+(\mathrm{NDF}-\mathrm{NDFi})
$$

in which: DMpd = potentially digestible DM content of the forage (DM\%); 0.98 = digestible coefficient of the cell content; and NDF and iNDF = NDF and iNDF content of the forage, respectively (DM\%).

Analysis of variance was performed in a completely randomized design, using Proc Mixed from SAS. The effects of sward height and grazing periods and their interaction were considered as fixed factors. The days of the grazing period were considered as a split plot in time. All means were compared by Tukey's test, adopting a probability level of 0.10 for Type I error.

$$
Y i j k=\mu+A i+B j+(A B) i j+\varepsilon i j k
$$

Where:

$$
\begin{gathered}
\text { Yijk = response variable; } \\
\mu=\text { mean of the experiment; }
\end{gathered}
$$

$\mathrm{Ai}=$ pasture height at the beginning of the deferment period effect

$B j=$ grazing period effect

$(A B) i j=$ the interaction effect between factor $A$ and factor $B$;

$\varepsilon i j \mathrm{k}=$ experimental error;

\section{Results and Discussions}

Reducing pasture height at the beginning of the deferment period (PHBD) has been recommended as a strategy to improve the nutritional value of deferred pasture (Sousa et al., 2012; Santos et al., 2013). This objective was partially met in our work, as the decrease in PHBD resulted in deferred pastures with higher content of potentially digestible dry matter (pdDM) in the simulated grazing samples. In fact, pdDM contents were higher and similar in pastures maintained at 15 and $25 \mathrm{~cm}$ than in those with 35 and $45 \mathrm{~cm}$ (Table 2) at the beginning of the deferment period. Furthermore, NDF content was lower and the digestibility of $\mathrm{CP}$ and NDF were higher in 15 and $25 \mathrm{~cm}$ deferred pastures, than in pastures with $35 \mathrm{~cm}$ at the beginning of the deferment period, except for pastures lowered to $45 \mathrm{~cm}$. On the other hand, in the middle and end of the grazing period, NDF content and the digestibility of CP and NDF did not show a well-defined response pattern, in relation to the studied heights.

The greatest difference in nutritional value between pastures subjected to PHBD occurred mostly at the beginning of the grazing period, because during this period the animals were consuming the upper layer of the pastures. In this layer, there may have been greater morphological differentiation between pastures, such as the predominance of live leafe in pastures with 15 and $25 \mathrm{~cm}$ and more inflorescences and stems in those deferred with 35 and $45 \mathrm{~cm}$. On the other hand, in the middle and end of the grazing period, animals probably consumed the most basal strata of pastures, where stems and dead forage prevails, regardless of the previous management used (Vendramini et al., 2019). This may have contributed to the absence of a well-defined response for nutritional value in the middle and end of the grazing period. Furthermore, at the end of the grazing period (September), started the rainy season (Table 1), which favored the appearance of young tillers at different levels between pastures. 
This may have been another factor interfering with the morphology of the most basal layer of the pasture, which also contributed to the lack of a well-defined response pattern for many nutritional value variables.

\section{Table 2}

Effect of reducing pasture height at the beginning of the deferment period on crude protein (CP) and potentially digestible dry matter (pdDM) in hand-plucking samples

\begin{tabular}{|c|c|c|c|c|c|}
\hline \multicolumn{6}{|c|}{ PHBD } \\
\hline & $15 \mathrm{~cm}$ & $25 \mathrm{~cm}$ & $35 \mathrm{~cm}$ & $45 \mathrm{~cm}$ & P-value \\
\hline $\mathrm{CP}\left(\mathrm{g} \cdot \mathrm{kg}^{-1}\right)$ & $69.8 a b$ & $72.1 \mathrm{ab}$ & $62.1 \mathrm{~b}$ & $81.8 a$ & 0.0252 \\
\hline pdDM(g.kg $\left.{ }^{-1}\right)$ & $797.1 a$ & 797.9a & $771.6 \mathrm{~b}$ & $766.6 b$ & 0.007 \\
\hline
\end{tabular}

PHBD: Pasture Height at the Beginning of the Deferment.

Less shading inside canopies with lower heights (Vilela et al., 2013; Paciullo et al., 2011; Pereira et al., 2011) probably caused lower senescence and stem elongation before and during the deferment period. Thus, deferred pastures with lower heights had better morphological composition. In this sense, Afonso et al. (2018), in a study conducted concurrently in the same experimental area, verified that 15 and $25 \mathrm{~cm}$ deferred pastures had a higher percentage of live leaves in the simulation grazing samples, compared to the $35 \mathrm{~cm} 45 \mathrm{~cm}$ deferred pastures. Corroborating this, Santos et al. (2008) also reported a negative correlation between dead stem mass and pdDM content (-0.85), but the correlation was positive between live leaf blade mass and pdDM content (+0.94) in deferred signalgrass (Brachiaria decumbens cv. Basilisk) pastures.

The improvement in the nutritional value of the forage apparently ingested by sheep, promoted by the reduction in PHBD did not cause variations in pasture consumption by the animals. DMl, expressed as percentage of body weight (\%BW), ranged from 1.10 to 1.63. Similar DMI values were observed by
Carvalho et al. (2021) when offering Brachiaria brizantha cv. Marandu at high developmental stage and chopped for crossbred Santa Inês and SRD sheep, with a body weight of $43 \mathrm{~kg}$. These authors obtained forage DMI of $0.96 ; 1.23 ; 1.3 \% \mathrm{BW}$, when animals fed mineral supplement, mineral supplement plus urea and low intake protein supplement, respectively. In this context, it is possible that high fiber ingested, ranging from 0.9 to $1.2 \%$ body weight, caused rumen filling and, therefore, promoted the physical expansion of this organ, which may have feed intake limited by ruminal filling (Mertens, 1994; Ferreira et al., 2013).

Regarding the grazing period, this factor influenced, the following characteristics: CP, pdDM, iNDF contents, DM, CP and NDF intake, as well as DM digestibility (Table 3). At the beginning of the grazing period, there were higher content of pdDM, CP and DM digestibility (DDM) in the simulated grazing samples (Table 2; $P<0.10$ ) which were due to the higher percentage of live leafe and lower percentage of dead stem in these samples during the beginning of the grazing 
period, as verified by Afonso et al. (2018) in a simultaneous study carried out in the same experimental area. During the period of use deferred pastures, in the winter, climatic conditions (temperature, photoperiod and, mainly, water availability) are limiting to pasture growth (Table 1). In fact, during the dry season, live leaves are preferably consumed by grazing animals and not replaced via regrowth. Furthermore, the limiting climate also causes greater senescence of leaves and tillers (Santos et al., 2017). All these factors contribute to decrease live leaf mass and, concomitantly, to increase the amount of dead material in pastures throughout the grazing period, as verified by C. S. Silva et al. (2016) working with marandu grass. The consequence of these morphological changes in the pasture is the variation in the nutritional value of the diet ingested by the animals throughout the grazing period. In this sense, in agreement with our results, Santos et al. (2008) observed that contents of CP, pdNDF and pdDM were linearly reduced, while the percentages of NDF and iNDF increased during the grazing period. For this reason, these authors concluded that, for the same stocking rate, the adoption of long grazing periods during the winter results in a reduced nutritional value of the deferred pasture.

\section{Table 3}

Effect of grazing period on nutrient content present in hand-plucked samples and nutrient intake and dry matter digestibility in sheep during the grazing period on deferred pastures

\begin{tabular}{|c|c|c|c|c|}
\hline \multicolumn{5}{|c|}{ Grazing Period } \\
\hline & Beginning & Middle & End & Value P \\
\hline $\mathrm{CP}\left(\mathrm{g} \cdot \mathrm{kg}^{-1}\right)$ & $94.1 a$ & $65.9 b$ & $45.0 \mathrm{c}$ & $<0.001$ \\
\hline pdDM (g.kg-1) & $838.8 a$ & $771.9 b$ & $739.2 c$ & $<0.001$ \\
\hline iNDF (g.kg-1) & $152.9 \mathrm{c}$ & $208.1 \mathrm{~b}$ & $245.5 a$ & $<0.001$ \\
\hline Intake(g.animal-1) & $487.29 a$ & $332.59 b$ & $384.19 b$ & $<0.001$ \\
\hline Intake (\% BW) & $1.63 a$ & $1.10 b$ & $1.23 b$ & 0.085 \\
\hline $\mathrm{CPI}\left(\mathrm{g}\right.$ animal $\left.^{-1}\right)$ & $1.64 a$ & $1.33 b$ & $1.22 \mathrm{c}$ & $<0.001$ \\
\hline $\operatorname{NDFI}\left(g\right.$ animal $\left.^{-1}\right)$ & $314.53 a$ & $244.07 b$ & $297.05 a$ & $<0.001$ \\
\hline DDM (\%) & $51.54 a$ & $28.62 c$ & $37.49 b$ & $<0.001$ \\
\hline
\end{tabular}

Averages followed by different letters, uppercase letters in the same row and lowercase letters in the same column, are significantly different $(P<0.10)$ by Tukey's test. Daily intake of dry matter $(\mathrm{DMI})$, crude protein intake $(\mathrm{CPI})$, insoluble neutral detergent fiber (NDFI), dry matter digestibility (DMD) and content of crude protein (CP), potentially digestible dry matter (DMpd) and indigestible insoluble neutral detergent fiber (NDFi).

The same response observed for the nutritional value occurred for DMI, both expressed in g per day and as percentage of body weight (\%BW), and also for the $\mathrm{CP}$ intake (CPB). These were higher at the beginning than at the middle and end of grazing period (Table 2). These results occurred because at the beginning of grazing period there was a greater mass of forage available and, indeed, superior forage allowance for animal grazing. 
Additionally, at the beginning of the grazing period, the pastures also contained a higher percentage of live leaves, which was found by Afonso et al. (2018). These better quantitative and structural characteristics of deferred pastures at the beginning of the grazing period probably facilitated the forage seizure process by the animal during grazing (Trindade et al., 2007) and, in effect, resulted in higher DM and CP intake (Table 3). In fact, a canopy structure is extremely important as it determines the ease of harvesting the component, usually selected by grazing animals and affect and the amount of ingested nutrients (Stobbs, 1973). In this context, Chacon and Stobbs (1976) concluded that the live leaf is the morphological component that most affects the intake of grazing animals.

On the other hand, higher intake of NDF (CFDN) occurred at the beginning and end of the grazing period (Table 3 ). At the beginning of use of deferred pastures, it was observed that sheep consumed many inflorescences present in the upper layer of deferred pastures. This may have increased the NDF intake at the beginning of the grazing period. Furthermore, the high DMl at the beginning of the grazing period, due to greater forage allowance with more live leaves, by itself, also justifies the higher NDF intake in this period. At the end of this period, pastures had higher percentage of dead stem, as identified by Afonso et al. (2018) in a study carried out simultaneously in the same experimental area; as this morphological component has higher NDF content, this caused greater NDF intake. Accordingly, M.E. R. Santos, Fonseca, Balbino, Gomes, \& Silva (2010) found that NDF and iNDF contents of the deferred pasture of Brachiaria decumbens cv. Basilisk were positively correlated with dead stem component.
There was interaction effect of PHBD with grazing periods for the following variables: NDF content and digestibility of CP and NDF ( $P<0.10$; Table 4). At the beginning of the grazing period, higher NDF contents were observed in deferred pasture with $35 \mathrm{~cm}(\mathrm{P}<0.10$; Table 4), probably due to the higher concentration of dead stem in this pasture (Afonso et al., 2018), a morphological component that contains a high content of NDF (Santos et al, 2010). The high presence of dead stem in the deferred pasture can lead to a greater intake of this morphological component by grazing animals as the period of use of pastures progresses. On the other hand, a higher NDF content was not identified in the $45 \mathrm{~cm}$ deferred pasture at the beginning of the deferral. The $35 \mathrm{~cm}$ deferred sward also presented lower digestibility of CP and NDF at the beginning of the grazing period $(\mathrm{P}<0.10$; Table 4$)$, which is consistent with the high percentage of dead stem and the low percentage of live leaves in this pasture, which was verified by Afonso et al. (2018) in a study carried out concurrently in the same experimental area.

In general, in the middle and end of grazing period, a lower NDF content was found in the $15 \mathrm{~cm}$ deferred pasture, which had better morphology, with higher percentage of live leaves and a lower percentage of dead stem (Afonso et al., 2018). These results are because live leaf blade is the morphological component with the better nutritional value, with lower NDF and iNDF contents (Santos et al., 2008).

At the beginning of period of use of the deferred pastures, lower CP digestibility was observed in the deferred pasture with 35 $\mathrm{cm}$, due to its lower percentage of live leaves, but higher percentages of dead leaf and stem (Afonso et al., 2018). 
Our results indicate that grazing periods determine the nutritional characteristics of the deferred pasture during the winter. This was due to two main factors. First, lowering the pasture during grazing causes changes in pasture structure, characterized by reducing the mass of live leaf (Afonso et al., 2018). In addition, adverse winter weather also drastically reduces pasture leaf growth (A. F. Sbrissia, Schmitt, Duchini, Silva, 2021). Thus, in order to overcome the problems arising from the loss of nutritional value of the pasture and the decrease in consumption by animals during the winter period, an appropriate strategy is the use of different supplements over the grazing period. In this context, it is recommended to make adjustments in amounts and levels of protein and energy of concentrate supplements to be supplied to grazing animals during the period of use of deferred pastures, in order to better meet the demand for nutrients by the animals.

\section{Table 4}

Interaction effect between reducing pasture height at the beginning of the deferment period (PHBD) and grazing period on the fiber content and nutrient digestibility in sheep on deferred pastures during the grazing period

\begin{tabular}{|c|c|c|c|}
\hline \multirow{3}{*}{ PHBD } & \multicolumn{3}{|c|}{ Grazing Period } \\
\hline & Beginning & Middle & End \\
\hline & \multicolumn{3}{|c|}{$\operatorname{NDF}\left(g^{\prime} \cdot \mathrm{kg}^{-1}\right)$} \\
\hline $15 \mathrm{~cm}$ & $640.8 \mathrm{Cb}$ & $712.5 \mathrm{Bb}$ & 745.9Ab \\
\hline $25 \mathrm{~cm}$ & $652.6 \mathrm{Cb}$ & 720.1Bab & 773.4Aa \\
\hline $35 \mathrm{~cm}$ & $676.3 \mathrm{Ca}$ & 739.9Ba & 775.9Aa \\
\hline \multirow[t]{2}{*}{$45 \mathrm{~cm}$} & $643.9 \mathrm{Cb}$ & 721.8Bab & 787.6Aa \\
\hline & \multicolumn{3}{|c|}{ CP digestibility (\%) } \\
\hline $15 \mathrm{~cm}$ & 61.09 Aab & $18.85 \mathrm{Bc}$ & 27.01 Bab \\
\hline $25 \mathrm{~cm}$ & $64.55 \mathrm{Aa}$ & $24.66 \mathrm{Bbc}$ & $34.47 \mathrm{Ba}$ \\
\hline $35 \mathrm{~cm}$ & $51.84 \mathrm{Ab}$ & 32.78 Bab & 30.66 Bab \\
\hline \multirow[t]{2}{*}{$45 \mathrm{~cm}$} & $64.60 \mathrm{Aa}$ & $37.41 \mathrm{Ba}$ & $19.48 \mathrm{Cb}$ \\
\hline & \multicolumn{3}{|c|}{ NDF digestibility (\%) } \\
\hline $15 \mathrm{~cm}$ & 53.98Aa & $30.38 \mathrm{Bb}$ & $37.35 \mathrm{Ba}$ \\
\hline $25 \mathrm{~cm}$ & 53.87Aa & 33.06 Bab & 41.57 Ba \\
\hline $35 \mathrm{~cm}$ & $45.57 A b$ & $40.79 \mathrm{ABa}$ & $37.40 \mathrm{Ba}$ \\
\hline $45 \mathrm{~cm}$ & 52.16Aab & $29.09 \mathrm{Cb}$ & 38.37 Ba \\
\hline
\end{tabular}

Averages followed by different letters, uppercase letters in the same row and lowercase letters in the same column, are significantly different $(P<0.10)$ by Tukey's test. PHBD: Pasture Height at the Beginning of the Deferment; CP: crude protein; NDF: insoluble neutral detergent fiber. 
Based on our results, one of our hypotheses was partially accepted, as the use of lower pasture heights at the beginning of the deferment period enabled the production of a sward with better nutritional quality, but these nutritional changes of the pasture were insufficient to generate greater nutrient intake and digestibility. Despite this, in a work developed concurrently in the same experimental area, Afonso et al. (2018) concluded that maintaining marandu grass at $15 \mathrm{~cm}$ at the beginning of deferral increases sheep performance in winter.

Furthermore, the other hypothesis was fully accepted, given that there was a reduction in the nutritional value of the forage apparently consumed by sheep, in the intake and digestibility of deferred pastures throughout the grazing period, in winter.

\section{Conclusions}

Maintaining $15 \mathrm{~cm}$ pasture height at the beginning of the deferment period improves the nutritional value of deferred forage and nutrient digestibility at the beginning of the grazing period, however it does not change intake by sheep during the winter.

The nutritional value and intake of deferred forage by sheep are compromised during the grazing period in the winter.

\section{References}

Afonso, L. E. F., Santos, M. E. R., Silva, S. P., Rêgo, A. C., Fonseca, D. M., \& Carvalho, B. H. R. (2018). O capim-marandu baixo no início do diferimento melhora a morfologia do pasto e aumenta o desempenho dos ovinos no inverno. Arquivo Brasileiro de Medicina Veterinária e Zootecnia, 70(4), 1249-1256. doi: 10.1590/1678-4162-10 130

Almeida, P. J. P., Pereira, M. L. A., Azevedo, S. T., Pedreira, M. S., Souza, D. R., Silva, T. V. B. S.,... Santos, E. J. (2009). Comportamento ingestivo de ovinos santa Inês mantidos em pastagem de capim urocloa (Urochloa mosambicensis (hack) daudy) com suplementação no semi-árido. Anais do $18^{\circ}$ Congresso Brasileiro de Zootecnia FZEA/USP-ABZ, Zootec, Águas de Lindóia, $\mathrm{SP}$, Brasil.

Alvares, C. A., Stape, J. L., Sentelhas, P. C., Gonçalves, J. L. M., \& Sparovek, G. (2013). Köppen's climate classification map for Brazil. Meteorologische Zeitschrift, 22(6), 711-728. doi: 10.1127/09412948/2013/ 0507

Alves, F. G. S., Felix, B. A., Peixoto, M. S. M., Santos, P. M. dos, Costa, R. B. da, \& Oliveira, R. S. de. (2014). Considerações sobre manejo de pastagens na região semiárida do Brasil: uma revisão. Revista Brasileira de Higiene e Sanidade Animal, 8(4), 259284. doi: 10.5935/1981-2965.20140148

Association of Official Analytical Chemists (1990). Official methods of analysis (15nd ed.). Arlington, VA: Association of Official Analytical Chemists.

Cantarutti, R. B., Alvares Venegas, V. H., Ribeiro, A. C. (1999). Amostragem de solo. In: A. C. Ribeiro, P. T. G. Guimarães, V. H. Alvares Venegas (Eds.). Recomendação para o uso de corretivos e fertilizantes em Minas Gerais: $5^{a}$ aproximação (pp. 13-20). Viçosa: Comissão de Fertilidade do Solo do Estado de Minas Gerais. 
Carvalho, B. H. R., Pereira, L. E. T., Sbrissia, A. F., Rocha, G. O., \& Santos, M. E. R. (2021). Height and mowing of pasture at the end of winter modulate the tillering of Marandu palisadegrass in spring. Tropical Grasslands - Forrajes Tropicales, 9(n¹), 13-22. doi: 10.17138/tgft(9)13-22

Chacon, E., \& Stobbs, T. H. (1976). Influence of progressive defoliation of a grass sward on the eating behavior of cattle. Australian Journal of Agricultural Research, 27(n5), 709-727.

Ferreira, S. F., Freitas, M. D., Neto, Pereira, M. L. R., Melo, A. H. F., Oliveira, L. G., \& J. T. N., Neto. (2013). Fatores que afetam o consumo alimentar de bovinos. Arquivos de Pesquisa Animal, 2(1), 9-19.

Mertens, D. R. (1994). Regulation of forage intake. In G. C. Fahey Jr., L. E. Moser, D. R. Mertens (Eds.), Forage quality, evaluation and utilization (pp. 450-493). Madison, WI: American Society of Agronomy, Crop Science of America, Soil Science of America.

Mertens, D. R. (2002). Gravimetric determination of amylase-treated neutral detergent fiber in feeds with refluxing in beaker or crucibles: collaborative study. Journal of AOAC International, 85(6), 1217-1240.

Moraes, E. H. B. K., Paulino, M. F., Zervoudakis, J. T., Valadares, S. C., Fo., \& Moraes, K. A. K. (2005). Avaliação qualitativa da pastagem diferida de Brachiaria decumbens Stapf., sob pastejo, no período da seca, por intermédio de três métodos de amostragem. Revista Brasileira de Zootecnia, 34(1), 30-35. doi: 10.1590/s15 16-35982005000100004
Paciullo, D. S. C., Fernandes, P. B., Gomide, C. A. M., Castro, C. R. T. de, Sobrinho, F. S., \& Carlos Carvalho, A. B., (2011). The growth dynamics in Brachiaria species according to nitrogen dose and shade. Revista Brasileira de Zootecnia, 4O(2), 270-276. doi: 10.1590/S1516-35 982011000200006

Paula, C. C. L., Euclides, V. P. B., Lempp, B., Barbosa, R. A., Montagner, D. B., \& Carloto, M. N. (2012). Acúmulo de forragem, características morfogênicas e estruturais do capim-marandu sob alturas de pastejo. Ciência Rural, 42(11), 2059-2065. doi: 10.1590/S0103-847820 12005000084

Paulino, M. F., Detmann, E. D., \& Valadares, S. C., $F^{\circ}$. (2008). Bovinocultura funcional nos trópicos. Anais do Simpósio Internacional de Produção de Gado de Corte, Viçosa, MG, Brasil. 2.

Pereira, V. V., Fonseca, D. M., Martuscello, J. A., Braz, T. G. S., Santos, M. V., \& Cecon, P. R. (2011). Características morfogênicas e estruturais de capim mombaça em três densidades de cultivo adubado com nitrogênio. Revista Brasileira de Zootecnia, 4O(12), 2681-2689. doi: 10.1590/S151635982011001200010

Saliba, E. O. S., Faria, E. P., Rodriguez, N. M., Moreira, G. R., Sampaio, I. B. M., Saliba, J. S.,... Borges, A. L. C. C. (2015). Use of infrared spectroscopy to estimate fecal output with marker Lipe. International Journal of Food Science, Nutrition and Dietetics, 4(1), 1-10. doi: 10.19070/23263350-SI04001

Santana, S. S., Fonseca, D. M. da, Santos, M. E. R., Sousa, B. M. L., Gomes, V. M., \& 
Nascimento, D., Jr. (2014). Initial height of pasture deferred and utilized in winter and tillering dynamics of signal grass during the following spring. Acta Scientiarum: Animal Sciences, 36(1), 17-23. doi: 10.4025/actascianimsci.v36i1.20463

Santos, M. E. R., Ávila, A. B., Carvalho, A. N., Rocha, G. O., Cleef, F. O. S., Segatto, B. N.,... Pereira, R. S. (2018). Estratégias para o rebaixamento do capim-marandu no início do período de diferimento e seus efeitos sobre o perfilhamento. Boletim de Indústria Animal, 39(4), 1617-1626. doi: 10.5433/1679-0359.2018v39n4p1617

Santos, M. E. R., Fonseca, D. M., Balbino, E. M., Gomes, V. M., \& Silva, S. P. (2010). Correlações entre características estruturais e valor nutritivo de perfilhos em pastos de capim-braquiária diferidos e adubados com nitrogênio. Revista Brasileira de Saúde e Produção Animal, 11(3), 595-605.

Santos, M. E. R., Fonseca, D. M., Euclides, V., Ribeiro, J. I., Jr., Balbino, E. M., \& Casagrande, D. (2008). Valor nutritivo da forragem e de seus componentes morfológicos em pastagens de Brachiaria decumbens diferida. Boletim de Indústria Animal, 65(4), 303-311.

Santos, M. E. R., Sousa, B. M. L., Rocha, G. O., Freitas, C. A. S., Silveira, M. C. T., \& Sousa, D. O. C. (2017). Pastures managed with variable nitrogen doses and deferment periods. Ciência Animal Brasileira, 18(1), 1-13. doi: 10.1590/1089-6891v18e-37547

Santos, M. E. R., Teixeira, M. C., Mesquita, S. V., Fonseca, G. D. M., Sousa, B. M. L., \& Santos, A. D. (2013). Pasture height at the beginning of deferment as a determinant of signal grass structure and potential selectivity by cattle. Acta Scientiarum: Animal Sciences, 35(4), 379-385. doi: 10.4025/actascianimsci.v35i4.20421

Sbrissia, A. F., Schmitt, D., Duchini, P. G., \& Silva, S. C. da. (2021). Unravelling the relationship between a seasonal environment and the dynamics of forage growth in grazed swards. Journal of Agronomy and Crop Science, 206, 630-639. doi: 10.1111/ jac. 12402

Silva, C. S., Montagner, D. B., Euclides, V. P. B., Queiroz, C. A., \& Andrade, A. S. (2016). Steer performance on deferred pastures of Brachiaria brizantha and Brachiaria decumbens. Ciência Rural, 46(n¹1), 1998-2004. doi: 10.1590/0103$8478 \mathrm{cr} 20151525$

Silva, P. H. F., Carvalho, C. A. B., Malafaia, P., Garcia, F. Z., Peres, A. A. C., Souza, P. M.,... Ferreira, R. L. (2019). Análise bioeconômica de períodos de suplementação proteicoenergética na estação seca para novilhas Nelore em pastagem diferida de Urochloa decumbens. Arquivo Brasileiro de Medicina Veterinária e Zootecnia, 71(3), 1058-1066. doi: 10.1590/1678-4162-10 511

Sousa, B. M. L., Andreza, H. H. V., Santos, L., Santos, M. E. R., Nascimento, D., Jr., Assis, C. Z.,... Rocha, G. O. (2012). Piata palisadegrass deferred in the fall: effects of initial height and nitrogen in the sward structure. Revista Brasileira de Zootecnia, 41(5), 1134-1139. doi: 10.1590/S151635982012000500008

Stobbs, T. H. (1973). The effect of plant structure on the intake of tropical pastures. II. Differences in sward structure, nutritive 
value, and bite size of animals grazing Setaria anceps and Chloris gayana at various stages of growth. Australian Journal of Agricultural Research, 24(6), 821-829. doi: 10.1071/AR9730821

Trindade, J. K., Silva, S. C. da, Souza, S. J., Jr., Giacomini, A. A., Zeferino, C. V., Guarda, V. D. A., \& Carvalho, P. C. F. (2007). Composição morfológica da forragem consumida por bovinos de corte durante o rebaixamento do capimmarandu submetido a estratégias de pastejo rotativo. Pesquisa Agropecuária Brasileira, 42(6), 883-890. doi: 10.1590/ S0100-204X2007000600016

Valente, T. N. P., Detmann, E., Queiroz, A. C., Valadares, S. C., Fo., Gomes, D. I., \& Figueiras, J. F. (2011). Evaluation of ruminal degradation profiles of forages using bags made from different textiles. Revista Brasileira de Zootecnia, 40(11), 2565-2573. doi: 10.1590/S1516-359820 11001100039
Vendramini, J. M. B., Sollenberger, L. E., Oliveira, F. C. L., Herling, V. R., Gomes, V. C., Sanchez, J. M.D., \& Yarborough, J. K. (2019). Herbage characteristics of continuously stocked limpograss cultivars under stockpiling management. Crop Science, 59, 28862892. doi: 10.2135/cropsci2019.05.0299

Vilela, H. H., Sousa, B. M. L., Santos, M. E. R., Santos, A. L., Assis, C. Z., Rocha, G. O.,... Nascimento, D., Jr. (2012). Forage mass and structure of piatã grass deferred at different heights and variable periods. Revista Brasileira de Zootecnia, 41(7), 1625-1631. doi: 10.1590/S1516-359820 12000700010

Vilela, H. H., Sousa, B. M. L., Santos, M. E. R., Santos, A. L., Silva, N. A. M., \& Nascimento, D., Jr. (2013). Characterization of tillers of piata palisade grass deferred in the fall with varying heights and deferment periods. Acta Scientiarum. Animal Sciences, 35(1), 21-27. doi: 10.4025/actascianimsci.v35 i1.13201 